\section{THE DR. F. M. NEWTON FUND.}

To the Editor of THE LANCET.

SIR,-Dr. Francis Morley Newton, medical officer of the Stoke-on-Trent Union Hospital, who died on Feb. 15th, 1920, left a widow and four children, aged $8,7,6$, and $1 \frac{1}{2}$ years respectively. He suffered from asthma and diabetes and was unable to insure his life or to make provision in any other way for his family, so that their present financial position and future prospects are precarious. A fund in aid of the widow and children has been opened under a committee having for chairman Mr. R. H. Dickson, F.R.C.S. Irel., President of the North Staffordshire Medical Society, and Mr. W. Webster, F.R.C.S. Edin., as secretary.

Dr. Newton was educated at Epsom College and St. Bartholomew's Hospital. The committee feels that his friends or fellow students might wish to contribute to this fund, and takes the opportunity offered by your columns to reach them. Contributions will be gratefully acknowledged either by the chairman or secretary. I am, Sir, yours faithfully,

WM. WEBSTER,

Secretary to the Fund.

64, King-street, Newcastle-under-Lyme, Staffs, March 26th, 1921.

\section{THE LABELLING OF THYROID TABLETS.}

To the Editor of THE LANCET.

SIR,-We heartily support Dr. A. E. Carver's contention contained in his interesting letter in THE LANCET of March 12th on the prescribing of thyroid gland that the present slipshod method should be standardised. The dosage of all other widely used medicinal products is based on the dried substance, and why should an exception be made for thyroid gland? Would a pharmacist receiving a prescription for digitalis leaves assume for a minute that the doctor meant the moist as he did not state "exsic." or "desiccat.," and proceed to calculate how much of the dried powder he must dispense to be equivalent to the moist? What is absurd in the one case is equally absurd in the other. No doctor troubles himself about the ratio of dried product to moist for drugs other than thyroid. The system is purely a survival of a nonscientific basis.

Moreover, this mixed system is fraught with danger. For instance, a doctor prescribes 1 gr. of thyroid gland in tablet form and the pharmacist dispenses it, using, say, Jones's tablets, which are 1 gr. moist equivalent to 1/5 gr. dried substance. The patient now has a further supply, but from another pharmacist, who in this case, conforms to the B.P. standard and dispenses tablets which contain 1 gr. of the dried extract made by, say, Smith and Co. The patient finds a marked difference, it may be for the better or for the worse, and the doctor is puzzled. The prescriber never sees the bottle, and if he did most probably the issuing label would be covered by the pharmacist's dispensing label. We may add that in 1913 a paper was contributed from our laboratories to the Pharmaceutical Conference ${ }^{3}$ using the argument which Dr. Carver now employs. Martindale and Squire, our two leading authorities after the B.P., both adopt the dried substance as their standard, and many of the leading manufacturers do the same.

Our experience does not conform with that of Messrs. Parke, Davis and Co. that prescribers mean " moist," for we made a large number of inquiries, and always had the same reply, that the "dried" substance was intended. In several cases the prescriber stated that the initial doses were always experimental and tentative, and the real dose required could only be decided by trial and result. We hope that this correspondence will do something to bring about a uniformity of prescribing and dispensing based on a more scientific and uniform principle.

We are, Sir, yours faithfully, DUNCAN, FLOCKHART AND Co.

Edinburgh, March 22nd, 1921.

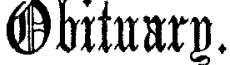

\section{RUTHERFOORD JOHN PYE-SMITH, CH.M. SHEFF.,} F.R.C.S. ENG.

EMERITUS PROFLSSOR OF SURGERY IN THE UNIVERSITY OF SHEFFIELD, AND CONSULTING SURGEON, SHEFFIELI ROYAL HOSPITAL.

WE regret to learn the death of Rutherfoord John Pye-Smith, lately professor of surgery in the University of Sheffield, whose retirement from the medical profession only dates from a few months ago.

Rutherfoord Pye-Smith came of old Sheffield stock, his grandfather, John Pye-Smith, D.D., F.R.S., his father, Mr. Ebenezer Pye-Smith, F.R.C.S., being both Sheffield men, though the latter practised in London, where his third son was born in 1848. Like an elder brother, Philip, R. J. Pye-Smith was educated at Guy's Hospital, from which he qualified in 1872, becoming F.R.C.S. three years later. In 1876 he went to Sheffield as a general practitioner. He soon made his mark as a man of exceptional skill and versed in modern surgical procedure, which was at that date undergoing a revolution. He was appointed in 1877 honorary surgeon to the Public Hospital and Dispensary (now the Royal Hospital), where he became the pioneer of Listerism in the district, and as such quickiy came into prominence. Younger men trained on the same lines soon appeared on the scene, but until his retirement Pye-Smith was always looked up to and respected as the doyen of surgery in Sheffield.

A colleague writes:-

When he began his career, like all other provincial surgeons of that time, he also carried on a general practice. In pre-Listerian days operative surgery alone was too scanty to provide a living, at any rate in the provinces, and it was necessary for surgeons to take genera. practice as well. Pye-Smith was almost the last of the local surgeons to do this, and he continued to do so more or less to the end of his career. As his surgical reputation grew and the amount of operative work demanded by the public increased, this combination of the two things made his work endless, and, as be could not bring himself to adopt modern labour-saving methods, it is difficult to understand how be got through his day's work. Motor-cars, typewriters, shorthand clerks - all these were anathema to him! For many years his single-horse brougham remained as the sole survivor of its kind amongst the profession! Every letter was in his own handwriting, and they were rarely less than four pagest No assistant prepared the patient for operation or pat on the dressings after operation! Everything he did was done from beginning to end by himself. Perhaps the most striking tribute to his capacity for work and his high sense of personal service, was the time which he devoted week by week to his hospital out-patients, even during the busiest part of his life. Four or five hours of his day, at least twice a week, would be given up to this part of his duties alone.

On the constitution of the University of Sheffield Pye-Smith was elected Professor of Surgery and gave long and valued services to the University, so that on retirement from his chair a few years ago he was rightly made Emeritus Professor, receiving also the honorary degree of M.Ch. in the University. In the affairs of the University, whether in the Faculty, Senate, or Council, he took an active part, rarely missing a meeting, while his frequent correction of the substance or the phraseology of the minutes or reports, of which he had always read every line, became a by-word amongst his colleagues. It was natural that he should be chosen to represent the University on the General Medical Council, where again his practical experience of the problems of education, learned in the evolution of the Sheffield Medical School, was often drawn upon by his colleagues.

During the war, though already showing distinct signs of strain from a life of incessant toil, he joined the staff of the Wharncliffe War Hospital, and in spite of remonstrances of friends, who saw how the work was telling upon him, he remained at his post until the conclusion of hostilities. But when the war was over he could not disguise from himself that his health was seriously affected, and a little less than two years ago 